\title{
Sufi Symbols In Poems Of Ibn 'Arabi And Hamzah Fansuri
}

\author{
Mazlina Parman*, Nurazmallail Marni \\ Islamic Civilization Academy, Universiti Teknologi Malaysia, 81310 UTM Johor Bahru, Johor \\ *Corresponding author: mąlina25@graduate.utm.my
}

\section{Article history}

Received: 2020-12-08 Received in revised form: 2021-02-23 Accepted: 2021-02-25 Published online: 2021-06-30

\begin{abstract}
As a way of communication, poetry is used by the Sufis to portray their knowledge and experiences in searching for God. However, the use of words in describing immaterial experiences spurs misconceptions among readers. Nevertheless, signs such as symbols are still being used in Sufi's poetry. It plays a key role in expressing mystical thoughts, myriad of emotions, and even uplifting our mundane spirits. This article explores the meaning of symbols in Ibn 'Arabi's and Hamzah Fansuri's poems. Both were known as prominent and controversially Sufi's figures in two different regions, the Arab World and the Malay Archipelago. In studying it, a semiotic approach is used whilst a comparative approach is carried out to differentiate the existence of influence between the two figures as the latter is influenced theologically with the first. The finding shows that there is a likeness in the use of symbols and meaning connotations brought about by Ibn ${ }^{\mathrm{c} A r a b i}$ and Hamzah Fansuri which proves the existence of influence between them, but variations are exhibited in the designation of the symbols which adhering to the different milieu, culture, and geographical places. Therefore, this study significantly indicating the authentication of Sufi poets in using symbols that portray the nation's culture and background. It also emphasizes the importance of interconnection between different cultures of Islam.
\end{abstract}

Keywords: Sufism, Ibn 'Arabi, Hamzah Fansuri, Comparative Literature, Sufi Symbols. 


\subsection{INTRODUCTION}

Poetry is an art built from creativeness and experiences in life. It is a mean of communication used to express emotions and experiences paved by its writer. Each poetry has its values, signs, and meanings. Poets use certain words creating signs to express their thoughts and emotions.

However, signs in poetry can lead to certain expressions and impressions that cause different comprehension by readers whereas the effects of poetry towards readers are never precise as they are elusive, evocative, and suggestive (Widdowson, 2000: p. 13; Johansen, 2002: p. 118-119). The elusiveness comes from the divergence of the reader hence, poets use ambiguous references or notion to achieve certain aims (Abdul Sattar, 2008: p. 801) that gives a characteristic feature of language may cause the differences.

As Sufis tend to use poetry as their means to convey mystical experiences and the bond they held with the Creator, certain words are used figuratively to describe the immaterial journey. These words are known as signs. Sign produces vague and obscure meanings for readers to comprehend, and Sufis have their own experiences hence, creating their signs varying these meanings. Therefore, this article aims to explore the signs used by the Sufis, especially Ibn 'Arabi and Hamzah Fansuri, sages of Sufis, using semiotic analysis and to define the influence that could be existed between the two of them.

\subsection{LITERATURE REVIEW}

The utterances of poetry are made up of several signs. It is a semiosis, a sign action that in approaching it Charles Sanders Peirce's sign theory can be utilized. To interpret signs, Peirce originated the triadic relation that adopted the term semiosis. Peirce divided signs into icons, indices, and symbols. The distinction of each is based on the representation function (Johansen, 2002: p. 29-30). An iconic sign is a sign of every object to which they happen to be similar example images, diagrams, and metaphors. An indexical sign is a sign of an actual relationship whereas a signifier is contiguous with its signified, or is a sample of it (Sebeok, 2001: p. 55), while a symbolic sign indicates given objects or states of affairs in the outer or inner world (Ibid: p. 31-38).

\subsection{Symbols in Sufi Poetry}

Symbols are significant elements in speech and pronunciation either directly or indirectly. It is defined as signals, using facial expressions or body movements (al-Fairuzabādī, 1996: p. 659; alTha $a^{c} \bar{a} l a b \overline{1}$, n.d.: p. 179) and something that implied in the word (Ibn Rashīq, 2001: p. 266). Symbolism refers to a style of literature that uses concrete words to describe abstract ideas, also mentions something to bring meaning other than the one mentioned and readers understand the meaning after interpreting it within its context (Rahman Shaari, 2001: p. 91). In other words, symbols are signifying ideas and qualities, by giving them metaphorical meanings that differentiate them from their literal sense.

Meanings can be derived from a symbol. Sabeok stated that it is a sign without either similarity or contiguity, but only with a conventional link between its signifier and its denotata, and with an intentional class for its designatum (Sabeok, 2001: p. 55). Hence, symbols initiating ambiguity in meaning or for some arbitrarily putting symbols in expressions. The arbitrariness of symbols (Carr, 2017: p171-192; Louwerse \& Qu, 2017: p. 849-855) infused more difficulty in understanding certain writings. The excessiveness of it indulges readers in confusion. Readers need to ponder as to understand reading materials, and misinterpretation may be resulting in polemics. Nevertheless, symbol characterizes Sufi's poetry. Sufi's poet uses it as a means of conveying the relationship 
between concrete experiences with mystical experiences. Thus, poetry lies equivalent within Sufi's thoughts for it voiced out a myriad of vague expressions (Zargar, 2016: 1-32). As stated by alQushayri (n.d.: p. 200), Sufis used symbols for them to understand the spiritual experiences they have been through and to elude their secret from becoming known to others, the non-Sufis. This is because the Sufis speak in an inner language beyond the limits of reason (al-Khatib, 1404H: p. 12-13) whereas theirs's experiences are likely to be misinterpreted, and surely not to discriminate others.

The complexity of symbols, the arbitrariness, and ambiguities do not preclude Ibn ${ }^{\mathrm{c}} \mathrm{Arabi}$ and Hamzah Fansuri to use symbols in their writings. Comparing both is significant, referring to the position of Ibn ${ }^{\mathrm{c}}$ Arabi in the Arab world and Hamzah Fansuri in the Malay Archipelago as each plays a certain part in placing Sufi poetry to a level of artistic and aesthetic values. In a way, many similarities and differences can be identified which gives us a clearer understanding of these two figures. Rohmana (2015: p. 1-27) identifies the locality and cultural traits shared between Hamzah Fansuri and Hj Hasan Mustapha in poetry, while Kamal (2017: p. 409-421) vindicates the similarities between the ontological views between Ibn Arabi and Spinoza. In Babakhani et al. (2017: p. 636-646) and Sharvani \& Sattar (2017: p. 1-18) comparison is made in distinguishing Ibn 'Arabi's thoughts. The concerns exhibited in the writings of the two sages reflect their mystical orientation. Both use conventional poetic metaphors and symbols to express the similarity in ontological views. However, Hamzah has transformed Malay literature at a different level during his time by originating mystical writing in Malay and influenced the entire Sufi poetry of the Malays.

\subsection{Ibn ${ }^{\mathrm{c} A r a b i}$ and Hamzah Fansuri}

Being called Shaykh al-Akbar by his followers, Ibn 'Arabi has spread his knowledge of Sufism towards human civilization from Andalusia to Anatolia. The teaching of his thoughts has not ceased so far but has spread to the East and West regions of the Arabian Peninsula, Africa, Iran, Turkey, Indo-Pakistan, the Malay Archipelago, the Mainland of China, including Europe and North America. The thought of Wihdat al-Wujüd and some of his metaphysical thoughts has been rejected by some prominent scholars such as Ibn Taymiyyah (d.728/1328), al-Khayyāt (d.811/1408), al-Biqa'i (d.875/1470), and others claiming that he has gone astray from the path of truth. However, some contemporary historians who had met him; such as Ibn Musdī (d.633/1234), Ibn al-Najjār (d.643/1245), Ibn al-Abbār (d.658/1268), and al-Tādilī (d.627/1230) did not write anything adverse about Ibn ${ }^{\mathrm{c}}$ Arabi.

The thought imaged by Ibn ${ }^{\mathrm{c}}$ Arabi is the inheritance of knowledge from the richness of the multicultural and religious cross-cultural traditions based on the Quran and as-Sunnah (Mohd. Sani, 2013: p. 26). Furthermore, his exploration of Andalusia and some other Muslim countries had given him a great opportunity to incur more experience and knowledge. Hence, giving symbol the privilege as the most important element in his poems to reflect his philosophical minds in a concise and metaphorical sense.

In the $17^{\text {th }}$ century, Ibn ${ }^{\mathrm{c}}$ Arabi thoughts were spread throughout the Malay Archipelago by Hamzah Fansuri, particularly in Acheh, Hamzah; who considered to be heterodox and deviated from the teachings of Islam received sharp criticisms from al-Raniri (al-Attas, 1970: 252-253); obtained Ibn ${ }^{\mathrm{c} A r a b i}$ thoughts during his journey (Ibid: p.3) to the Middle East such as the Arabian Peninsula, and Baghdad. He also went to Malaya like Pahang and Kedah, and Java. These journeys allowed him to master Arabic, Urdu, Persian, Malay, and some dialects in Java. But little is known about his background only that his name Fansuri refers to Fansur or Barus, a place located in North Sumatra believed to be his origin (Hasymy, 1976: p. 10). There is evidence that he lived 
between 1575M and 1625M during the reign of Sultan Ala al-Din Ri'ayat Syah (997-1011/15891602) and the early reign of Sultan Iskandar Muda Mahkota Alam in the early 17th century (Wan Mohd Saghir, 1996: p. 7) but Hamzah is mentioned only in some of al-Raniri's narrations and his poetry.

Hamzah wrote about religion includes the teaching of the Sufi path. His writings contributed to Malay literary development at the time which served as the fourth language of the world after Arabic, Persian, and Turkish Ottoman (DBP, 2004: p. 78). This is seen through his renowned trilogy, namely Asrär al-Ärifin, Syarab al-c Asyikin, and al-Muntahi, as well as several strings of poems survived from the obliteration of Sultan Iskandar Thani (1637-1641M) due to the indictment of his heresy. Even in Hikayat Aceh text the name of Hamzah Fansuri is not mentioned as a figure in literature and sufism but according to Muhammad Luthfi (2020) the survived works were spread by Hamzah's disciples.

The two figures faced similar journey in uphold their Gnostics ideas. Because of this, Ibn Arabi and Hamzah Fansuri became an attraction for modern scholars to explore more deeply on their works not only doctrines in Sufism but also in literatures. In that, studies have been conducted on their works such as symbolic meanings, poems in diwans and hermeneutical reading of the poems (Gril 2013; Cook \& Hirtenstein 2012; Syarifuddin 2017). Consequently, this article is significant in adding knowledge by comparing the two figures in comprehending symbolical meanings of their poems.

\subsection{METHODOLOGY}

The data of this study consists of the poems in Diwan Tarjuman al-Ashwaq written by Ibn ${ }^{c}$ Arabi. The translations in English were taken from the translations of Reynold A. Nicholson, an eminent English orientalist, scholar, and translator of both Islamic literature and Islamic mysticism. The Diwan is a small collection of Ibn 'Arabi's poems. It is accompanied by a commentary, in which the author himself explains the meanings conveyed throughout the poems. The Diwan sparks numerous condemnations from some devout Moslems as 'vain and amatorious' (Sa'diyya, 2012: p. 16). In refuting these criticisms, Ibn 'Arabi issued a commentary version containing the same poems and a preface in which he declares the place he composed the poems, which is the Holy Mecca.

While poems of Hamzah Fansuri were taken from the compilation of Drewes \& Brackels with translations in English. These poems are the earliest specimens contained in seven manuscripts (Drewes \& Brakel, 1986: p. 26-27). These poems are grouped into six which every group addressed certain aspects such as types of people in the Islamic community, Deity and His relationship to mankind, so-called bird-poems, primeval Ocean of the Divine Being, and fishpoems.

The data is analyzed using semiotic analysis focusing on symbolical signs. The extracted symbols are comprehended and interpreted to their meanings and explored the interaction between these symbols. This study tries to highlight words that are used by Sufi's poets in their poems and interpreting the reason behind these selected words. To Sufis, symbols are significant aspects in portraying their inner revelation of God. Thus, in retrieving the symbols three stages were done. Firstly, the selected text is reviewed attentively to identify symbols that can be derived from nature, names, cosmos, etc. This process has gone through word per word basis consolidate with the semiotic approach of Charles Sanders Peirce. This method logically determines the meaning of the symbols within two phases; the establishment phase and the interpretant phase. 
In the second stage, in recognizing the symbols as a medium to convey the mystical meaning; since not all the symbol related to Sufism; sources such as encyclopedias, books on Sufism and sources about Ibn 'Arabi and Hamzah Fansuri were referred to such as 'al-Futuhat al-Makkiyyah', Mu'jam al Istilah al Sufiyyah and al Ta'rifat.

The third stage is the data analyzing process within the comparative approach. Five phases were carried out to ensure the results of the study were well developed; data translation from Arabic/Malay to English, data coding according to theme, denotation and connotation process, data were referred to other sources as to bring up the intertextuality value; as Sufi's poets tend to use this style, and data comparison to see similarities and differences between these two poets.

\subsection{RESULTS AND DISCUSSIONS}

Symbol plays a significant role in conveying Sufi's spiritual experience. This mystical journey is above any language's capacity as it is beyond the human mind. Thus, this study highlighted five symbols frequently used in the studied poetry.

\subsection{Nature and Ruins}

Poets use natural sceneries because of their proximity to themselves. Desert, trees, sun, flashes of lightning, hills, stars, and valleys are some natural settings commonly used in poetry. Most of these can be found abundantly in Ibn 'Arabi's Tarjuman al-Ashwaq; are related to the poet's homeland, the places he had been to, or traits of his lover.

He saw the lightning in the east and he longed for the east, but if it had flashed in the west be would have longed for the west. (Ibn Arabi, 2005: p. 74)

The lightning symbolizes the manifestation (al-tajalli). In the verse, Ibn ${ }^{\mathrm{c} A r a b i}$ refers to the vision of God in created things and the manifestation in forms, and this causes him to cleave to phenomena because the manifestation appears in them. As the manifestation appears in the east, he will go there to seek it, even if it appears in the west, he will be there. Ibn ${ }^{\mathrm{c} A r a b i}$ emphasizes that it was not about the places as he will go there but it is all about the longing towards the manifestation.

'Twas in the glen of the valley of Qanat I met them, and my last sight of them was between anNaqa and al-Mushalshal. (Ibid, 180)

The intertwined road on the hills at the valley of Qanat, a place situated in Medina Munawwarah (the union with the Light of Muhammad); symbolizes the shifting of the mystical stage of a Sufi and the separation of each stage represented in the separation at the place.

Abodes and ruins of beloved ones are often found in love poetry during the Pre-Islamic Era. Ibn ${ }^{\mathrm{c}}$ Arabi uses the common description with deferent interpretation:

Halt at the abodes and weep over the ruins and ask the decayed habitations a question.

'Where are the loved ones? Where are their camels gone?' (They answer), 'Behold them traversing the vapour in the desert. (Ibid: p. 92)

The abodes symbolize the stations where Sufi alight during their journey to the infinite knowledge of their object of worship. The ruins and the decayed habitations portray sadness because there is no joy in the deserted abodes, and their very existence depends on those who dwell in them (Nesraoui, 2016: p. 8-20). 
Hamzah Fansuri's poems are contrasted. Even though Ibn 'Arabi's poetries full of abodes and ruins, Hamzah plainly stated only a few words about places he went and his origin.

Hamzah the stranger is a sacred bird

His house is the Frequented House' (Bayt al Ma'muri)

In this pre-existent state, he was intended for camphor

From the trees of the region of Fansur (Drewes \& Brakel, 1986: p.75)

He continuously changes His abode

Roaming around all the time

Like the magic jewel in the snake's mouth

He is most difficult to gain. (Ibid, 95)

Hamzah, astray in the forest

Went into a retreat for months and months

His narrow direction of prayer did not get beyond Paradise

Hence he was tardy in finding the Lord. (Ibid, p. 105)

Besides Kaaba, Hamzah used the Bayt al Ma'muri (al Quran, 52:4), a place in heaven where it corresponds directly with the Kaaba. It is frequented by the angels and near to the Kursi. The place itself is heavenly and its nearness to Kursi referring to the correlation of the Divine Being and creation. Hamzah integrated al Jili's notion about the Perfect Man (al-Insan al-Kami) by denoting these places and yet he also reminding himself as a low being that originated in Fansur, an earthly place.

In trying to ascend to the divine, Hamzah continuously roamed the world of being. The forest, a place of challenges and serenity is used as a retreat in God's search. Forest resembles the hardship and toils of a man in his gnostic journey.

\subsection{Birds, Camels, and Fishes}

Animals and birds are common symbols use in poetry. It can be interpreted in literal, cultural, religious, philosophical, and mystical traditions.

On the day of parting, they did not saddle the full-grown reddish-white camels until they had mounted the peacocks upon them,

Peacocks with murderous glances and sovereign power: thou wouldst fancy that each of them was a Balqis on her throne of pearls. (Ibn 'Arabi, 2005, p. 30)

Full-grown reddish-white camels are related to effort and determination. The camels are healthy and fit for long journeys. The peacocks, related to beauty, elegance, and lightness, symbolize the spirits of those actions, for no action is adequate until it has a spirit consisting in the desire of its doer. These two symbols reflect the ascending of one's good deeds to The Absolute. Ibn ${ }^{\mathrm{c}}$ Arabi emphasized the practice of virtue without the spirit is useless. 
In a verse, Ibn ${ }^{\mathrm{c}}$ Arabi associated the warble of a dove with one of the ways the Prophet Muhammad PBUH receiving the Revelation:

Woe is me, woe is me for a youth who, whenever a dove warbles, is made to vanish! (Ibid, p.

The verse states that the bearers of the inspiration that comes at the tinkling sound which is like the noise of a chain when it strikes a rock. They cause the heart to vanish, even as they vanish on hearing that sound. The similarity of the situation of these bearers is referred to the Prophet PBUH as he said that this manner of inspiration was the most grievous to him, and he used to pass away from his senses (Ibn Hajar al-Asqalānī, n.d., p. 24-25), and wrap himself until it departed after he had understood its meaning.

Ibn ${ }^{\mathrm{c}}$ Arabi also uses pigeons as a symbol of the spirit of affection. He stated:

A ringdove wailed, and a sad lover complained, and he was grieved by her thrilling note and complaint (Ibn 'Arabi, 2005, p. 67)

The ringdove with a collar points to the covenant which Allah laid upon her during the primordial life. As the dove calling with sweet melodies to the sad lover to union with her reflective the calling of God towards the man to unite with Him. This union is the first resurrection at death.

O doves that haunt the arake and ban trees, have pity! Do not double my woes by your lamentation!

(Ibid, p.58)

O dove on the ban tree at Dhat al-Ghada, I am oppressed by the burden thou hast laid upon me (Ibid, p. 190)

In these verses, the dove portrays The Absolute Wisdom, and the Dhat al-Ghada refers to states of self-mortification; the suppression of desires by self-discipline as an aspect of religious devotion. The state that burdened the Sufi is taken from the understanding of verse 72, Surah alAhzab. Dove with the Kalor and Arakah tree refers to the freedom from the shackles of this world tinged with a sense of the beauty of unification with the Creator.

Hamzah Fansuri also did not miss out on putting a bird in his threads of poem (Drewes \& Brakel, 1986, p. 121-123):

The yellow bird (Pingai) most intently,

Is forever disporting at the

The footstool of the Creator,

It is kind of the eminent Merciful, And most qualified for becoming a ruler.

The light-bird (Unggas Nuri) originates from the radiance,

Its permanent station is the Exalted Footstool (kursi),

from its light rich and poor

Lord and servant, all men derive.

Pingai; a golden and sparkling bird; connotated as soul and spirit in Malay culture (Kamus Dewan, see: pingai) is a symbol of the true self sought by a Sufi after going through the mystical path of Sufism. It also hinted at the transcendence of mortality. By using Burung Pingai, Hamzah 
Fansuri raises a polemical issue of namely one and many relationships, the manifestation of the Oneness in His creations.

In the second stanza, Hamzah describes the light-bird which springs from the divine light and has its permanent abode at the kursi which 'extended over the heavens and the earth (al-Quran, 2:255). He uses the bird and its radiance to transfuse the inner self to the heavenly world as achieved by a Sufi. The transcendence is brilliantly portrayed within the usage of the bird and the stating of kursi in this context is not God's throne but the footstool of the throne.

For Braginsky and Brakel, the word light bird (Nuri)' refers to the character of the bird. Taken from Arabic, it denotes light adhered by Hamzah to balance the poem's metre. But as in Malay culture, Nuri refers to a type of bird and is usually used in Malay literature. It represents the lord of the birds due to its privilege in speaking, beauty, and wisdom. But as Hamzah is well-known for his mastery in intertwining foreign words within his own, the Nuri opted to radiance and it symbolizes the genesis of human spirits giving birth to a myriad of stratum that lies within the word faqir (poor), kaya (rich), insan (man), tuan (lord), and sabaya (servant).

In some stanzas, Hamzah Fansuri pointing out the nature of the Pingai is differed from dove, whereas he said (Drewes \& Brakel, 1986, p. 123):

The yellow bird is not a dove

That coos day and night

Say, ob people of the earth

Hamzah Fansuri is already submerged

He also keeps repeating the state of the Pingai as a naked bird (Ibid, p.119):

That river is far superior

It is the watering-place of the naked bird

After swallowing a draught, it gets bewildered

The cup falls to pieces and the bottle breaks.

The naked bird's drunkenness is above reproach

As ensuing from a most profound knowledge of God

Such drunkenness is allowed even by the judge

Lord Abu al Qasim (the Prophet) setting the example.

The naked bird symbolizes an accomplished mystic who has freed himself from the earthly ties, having done away with all earthly attachments and attained union. Mystics wag the world away trying to attain ma'rifa (mystical knowledge). In attaining the ma'rifa, hunger and nakedness conducively applied within the tahalli, takhalli, and the tajalli (Abdul Fatah, 2006, p.26; Armstrong, 1995, p. 229-230).

The symbol of bird dominates Ibn 'Arabi and Hamzah's poetry as it is metonymical in origin (Ferber, 1999, p. 25) but often it is metaphorical. These two poets use the bird world as an analogy to human society. A bird is a symbol of innocence, flight, imagination, and desire (Sajad Hussain, 2016, p. 210). The use of this symbol is linked to divine inspiration, a spirit free from worldly 
bonds and has a sense of longing for its Creator. Both use the same image but differ from the bird's point of view. This is the result of different geographical backgrounds between the Arab and the Archipelago.

In other poems, Hamzah used unique fish and whales in describing the agitation of the primeval Ocean by the storm of creation. Both fishes are found in the China Sea, the sea known for its typhoons. The unique fish of human shape represents those who aware of their origin from the Nur Mubammad while the whale is the image of unenlightened people.

The unique fish is properly called accomplished,

It is in constant union with the water,

Most perfect in its love,

It lives in the shoreless ocean.

This fish is more exalted,

Its kind is the Light of the Merciful,

Its body is of human shape,

It is continuously sporting in the eternal Ocean. (Drewes \& Brakel, 1986, p. 137)

How strange that the whale (Gajahmina),

Having its babitat in the China Sea,

Looks for water on Mount Sinai,

Hence its efforts are worthless.

The China Sea is unfathomable,

For this reason, the population of the entire universe,

Jinn, angels and (the sons of) Adam,

All of us get submerged in that sea (Ibid, p. 141).

In these verses, Hamzah also portrayed the whale as a "peculiar whale" who searches for water in the desert of Mount Sinai, even though it lives in the China Sea. Hamzah satirically commented on people who seeking God outside of themselves. In these strings he argues that people are already at a union with God, and it is our duty to renouncing the world and recognizing the truth.

\subsection{Wine}

Wine plays a significant role in representing different stages of a mystic path (Sajad Hussain, 2016, p. 200-221). It represented the mystic quest, the mystic union, the mystic ecstasy, the mystic struggle, and the annihilation of a Sufi in a comprehensive manner.

When a Sufi reaches the level of annihilation, poets will describe it as a mystical intoxication as it is innate from the inner self. Ibn ${ }^{\mathrm{c}}$ Arabi adapted the drunkenness after taking liquor to the mystical intoxication of divine love which expressed joy and serenity to those who perceived it. 
And drink the pure essence of its wine with its intoxication, and listen rapturously to a singer who chanteth there:

'O the pure wine that in Adam's time related concerning the Garden of Eden an authentic tradition! (Ibn 'Arabi, 2005, p. 135-136).

The pure essence of the wine connotated spiritual meanings and Divine sciences, which fill the heart with delight. The singer, one of the characters found in Persian literature, symbolized the voice produced by the universal praise, the chanting; the human soul hears it in its essence and is enraptured. In the second verse, the singer describing the origin of the wine and its prestigious state from the Garden of Eden; the Presence which comes to abide in the souls of Gnostics at the time of nurture.

Ibn ${ }^{\mathrm{c}}$ Arabi chooses the best wine as the intermediary of the divine manifestation of every stage passed by the Sufis. Wine is also often associated with the annihilation of a servant of God in the presence of divine beauty. The annihilation is the best outcome for Sufi which is only given to individuals who attain gnostic realism. When exposed to the Creator's beauty, the Sufi become drunken and rejoiced with the melodious and enchanting song. This illustration is for those who desire the life of the Hereafter, and they worshiped God, pleading for His mercy and fear His chastisement.

Hamzah Fansuri uses the word shurbat to illustrate mystical intoxication but he denies it is wine. He also illustrates the shurbat in its best quality through clarity and purity. It is different from the wine made in this world as if he was hinting that the shurbat drunk by the people of Paradise refers to divine love.

A noble beverage out of the hand of the Creator,

Intended for lovers' drink,

Anyone partaking of it bursts into words,

And of right says, I am the Highest Reality.

This beverage is delicious,

And serves as a universal medicine,

Anyone partaking of it forgets the cup,

And turns into Mansur, the incomparable one.

This drink is not rice-wine,

It is incomparably inebriating,

In the cups of the servants,

Do not disregard this beverage (Drewes \& Brakel, 1986, p. 99-101).

Tell this to our lord the judge,

This drink (Shurbat) is pure and it's colour transparent,

Anyone drinking it gets inebriate and lost to this world,

He attains the Beloved Whose name is the Eternal. 
This drink (Shurbat) is not arak (wine),

It will never be distilled over a fire of this world,

Keep your distance from the fire of this world,

So that you may drink your fill of this beverage (Ibid, p. 107).

These verses clearly illustrate the bliss a Sufi receives in Union with the desired goal. The wine represents the achievement of that goal and a Sufi is blessed once he attains the ecstasy of witnessing God. His thirst is quenched with the wine of gnostic (oneness with the God) and he experiences the mystic bliss.

This drink is most rare

And so dear that all your riches cannot buy it

Do not care for your body of life

That is the price of this heady beverage

The naked bird's drunkenness is above reproach

As ensuing from a most profound knowledge of God

Such drunkenness is allowed even by the judge

Lord Abu 'l-Qasim (the Prophet) setting an example

The beverage is beyond compare

Even in the fasting-month, you are free to drink it

It is permitted to and good for all servants

Anyone partaking of it will be shielded from negligence (Ibid, p. 119)

In some stanzas, Hamzah related the shurbat with the naked bird as he is stating a situation whereas the shurbat was drunk by the naked bird making it drunk in a certain way that conveying the most profound knowledge of God. The priceless beverage, as Hamzah described is the waters from Paradise and it can be used at any time and permitted to anyone dead from the world and have soared to the divine sphere (the annihilation).

When reading Sufi poetry, one can see that wine has been used as a symbol in it dated back to the $2^{\text {nd }}$ century of Hijri by Zi al-Nun al-Misri (Nesraoui, 2016, p. 14). Various forms of wine are used to illustrate the drunkenness, loss of sanity, atmosphere, and so forth taken from the poetry of wine in the days of the Umayyad and Abbasid Kingdom (Orfali, 2017, p. 196). However, the Sufis alter the existing perception of alcohol by laying their intentions on such as drunkenness to inner consciousness, spaciousness refers to the narrowness, and so imagination, states, and stages. Each of them ends in annihilation in Divine love. Enriching it, Hamzah brought a new dimension to the wine. The mentions of shurbat in Hamzah's poetry differ from wine. When Hamzah depicted wine with the word pure and transparent, it refers to the purity of the drink because wine is not something sacred regarding the Malay Muslim society's understanding. 


\subsection{Femininity and Women}

Divine Love is the ultimate goal of every Sufi. The transition of the mystical stage occurs when only a Sufi experiences alteration in sense of longing, love, and content. For al-Qushayri (n.d., p.319), love is portrayed in the love of a slave of God to The Absolute purely flourished from his heart manifested within his soft speech, and his heart is constantly extending his feelings, arousing his pleasures, and it is so essential to him as he will be gone astray without it; calmness is only present when the touch of the love is in his heart.

Ibn ${ }^{\mathrm{c}}$ Arabi symbolizes the love of being to imply divine love. This symbol dominates his poetry in Diwàn Tarjumàn al-Ashwäq. He sees the element of feminism as a distinct feature in manifesting spiritual qualities, thus the love for the Absolute. For Ibn ${ }^{\mathrm{c}}$ Arabi, women are the supreme and sacred wisdom (Nasr, 1983, p. 192). It is also used as the image of Divine Wisdom (Ibn Arabi, 2005, p. 25-26). The selection of the female symbol occurred when he has acquired the enlightenment of the mystical stage passed (Lutfi, 1985, p. 7-19).

Which charm by their laughing and smiling mouths; whose lips are sweet to kiss;

Whose bare limbs are dainty; which have swelling breasts and offer choice presents (Ibn Arabi, 2005, p. 145-146).

The laughing and the smiling hint at the Sufi state of al-fahwaniyah (speaking to God) and affability. It is also an indication from the Absolute to the Prophet Muhammad PBUH in the descending of Gabriel within the form of good-looking man as if God speaks to the Prophet that there is nothing between us two except for beautiful images, as a cordial introduction.

The metaphorical images of a woman in these strains stated the acquisition of divine knowledge through the sense of touch. Ibn 'Arabi's feminine beauty is the description of a spiritual state, as it is a mirror image for a deeper spiritual truth.

And call Da'd and ar-Rabab and Zaynab and Hind and Salma and Lubna, and listen (Ibid, p. 39)

For Ibn 'Arabi, these women's names are Divine Realities according to their difference within the mystical stages, as they respond depends on the Sufi's stage. Thus, the Sufi may know his position regarding them.

For Ibn ${ }^{\mathrm{c} A r a b i}$ women are often associated with love. On this basis, he uses a female symbol in his poems as he sees women are creatures created by God to be loved and because women are part of a man's self. Thus, Ibn 'Arabi sees love for the three types of divine love, spiritual love, and natural love that all three returns to his thought that love is part of the unity of the beings Lutfi, 1985, p. 7-19) and the romantic communication between God and man (Jaberi, Imran Ho \& Vengadasamy, 2016, p. 143-156). For Ibn 'A Arabi, women satisfy the needs of men to achieve perfection. Women are one for a man to attain the perfection of self-righteousness. The occurrence of a woman from a man, as mentioned in the Qur'an (7:189), makes the woman a part that should be united with the man so that this man does not lose himself and fulfill the facultative and inner aspects of his quest for perfection.

Whereas in Hamzah's writing, feminine image failed to dominate. He does not often rely on this type of symbol. Only a few stanzas are portraying God with feminine traits in describing God's love for beauty, such as (Drewes \& Brakel, 1986, p. 85):

He wears flowers for pendants and is adorned with garlands, 
His vestures are many and various,

Sometimes be is concealed in a servant,

Hence people do not pay heed.

Referring to the stanza, the female image seems to be hidden from the public view. It is not directly disclosed and discussed openly due to the norm of the Malay community, after the arrival of Islam, which characterized women with shyness (Susanti, 2014, p. 226-236; Zurakintan \& Che Ibrahim, 2015, p. 121-129) and politeness in giving advice (Arina \& Indirawati, 2016, p. 73-94). Although, in the history of the Malay world, certain historical records portrayed traditional women as the weaker gender, were presented to someone as a symbol of appreciation, were assumed to be incapable, even were subjected to sexual needs of those in power causing less emphasized on their daily roles (Arba'iyah, 2020, p. 68), Hamzah Fansuri influenced by Ibn 'Arabi resisted the tradition and viewed the woman as mabbub, the loved one, symbolizing her to the Most Merciful and Loving God.

\subsection{Ocean, Boat, and Seafarer}

The ocean represents God's knowledge and its Divine secrets (al-Quran, 18:109). The nature of the ocean provides a mystical dimension bestowing the states of Sufi's experiences. Mahdavi sees the ocean, in it is single but has different forms of steam, rain, cloud, bubbles, waves that are emanated from the creatures. Being synchronize with the sea, a boat plays a significant role as a means to cross the ocean (Mahdavi, 2017, p. 817-824).

Despite this, Ibn 'Arabi's Tarjuman al-Ashwaq has lacked these symbols as the poetry revolves around a girl named Nizam, daughter of al-Asfahani whom he met during his journey to Mecca (Ibn Arabi, 2005, p. 13) where the ocean is beyond one's sight. Thus, in his other writing, he stated (Ibn Arabi, n.d., p. 20):

Look at the Throne on His water, a boat sails in His Names

And he marveled at Him from a revolving boat, that has deposited the creation with His bosom

He swims in the ocean without a coast, in the unseen and the darkness of the unseen

And His wave guides the states of His lovers, and His breeze the breath of His tidings

The Throne ushered the level of the Restricted Names of God that can only be revealed through God's spiritual unveiling. The mention of a boat, the ocean, the darkness of the ocean, the coast, the wave, and the breeze are describing the revelation of The Oneness in His creations as seen by the Gnostics.

In Hamzah's strings of the poem, one can see that the ocean significantly plays a big role in his life. There are three sea-poems written on the theme of God as the primeval Ocean (Drewes \& Brakel, 1986, p. 127, 129 \& 135). The symbol of waves meeting the Ocean portraying the relationship of God and the world.

Smooth is the course of the waves of benignity,

Do not give up yourself to the waves of omnipotence,

Earn your livelihood in an honest way,

So that the Endless Sea be pleased. 
You are a most luminous wave,

In you are both majesty and beauty,

In your acts are permitted your gain will be,

Hat you will belong to the fold of Mubammad (Ibid, p. 133).

Hamzah described the condition of a seafarer and the ocean with accuracy. In these stanzas, he advised any Sufi who wants to embark on the path of loyalty to be prepared as a seafarer before starting the journey.

Sit down on the upper deck of the ship,

Keep your anchor weighed,

Fit the bulwarks of the Law,

Lest your vessel swerve from its course

The helmsman knows the course,

He quietly sails the sea,

As your vessel is not made of boards,

It is without an equal (Ibid, p. 113).

The rogue waves or the serenity of the sea breeze, everything related to the ocean is a medium in perceiving God within oneself.

If you know yourself, dear sir,

You are the sea without compeer,

Waves and sea are not different,

Let this vision be steadily yours (Ibid, p. 131).

Smooth is the course of the waves of benignity,

Do not give up yourself to the waves of omnipotence,

Earn your livelihood in an bonest way,

So that the Endless Sea be pleased (Ibid, p. 135).

In the stanzas, Hamzah stated the importance of knowledge as it is the seven qualificator's attributes of the Essence. With the knowledge, man must recognize his true self, take refugee within it and return to the Ocean which is the very essence of his being.

Ocean and boat, the two symbols that always paired in Sufi's poetry stating a strong connection between them. The ocean was seen by Ibn ${ }^{\mathrm{c}}$ Arabi as changes of states traversed by Sufis. The ocean voices out the weariness and hardship, but it also displays beauty, longing, and love. Every person with different experiences with the ocean will give a different view. There's gratitude, hate, disappointment, and so on. Ibn 'Arabi emphasized these emotions within Sufi 
wayfarer as he has gone through the path and faced various challenges that arise. The change of ocean imagery implies this diversity but in the end, it is always connected with Divine Love.

Through the ocean, Hamzah described it as a meeting of man with the Divine within him. The depth of the ocean shows an unlimited distance between them. The preparation he requested, such as provisions, timber, rice which required a person before the cornerstone to be firmly established with the Sharia and became a trading boy deeply in the deep sea, i.e. a process of returning himself to the original, returning and disappearing in the same place. The dominance of the ocean symbolizes in Hamzah's work was not because of his reliance on Arabic and Persian poetry but because of his familiarity with the world of seafarers and the Qur'anic verses. At the same time, it played an important role in the shamanistic rites of peoples of the Malay Archipelago (Braginsky, 1975, p. 407-426).

\subsection{CONCLUSIONS}

Sufi poetry has the values of religious criticisms and distinctive symbols that reveal spiritual experiences and their relationship to the beauty of art. The use of nature, fauna, and bird reflects the soul of a Sufi that prepares for changes of spiritual stages, hence transforming himself. Thus, the bird is the closest living thing for Sufi's poet to imitate the freedom spirit of a Sufi in being a Perfect Man.

Although the use of symbols is also found in other genres of poetry, however, the classical images used by Ibn ${ }^{\mathrm{c} A r a b i}$ are much different. This occurs when Ibn ${ }^{\mathrm{c}}$ Arabi used the object of creation and transcends its meaning to manifest the divine meaning, because of mystical experience (Nasr, 1983, p. 302; Knysh, 1999, p. 11). Being in the mainstream of Neosufism (Jajang, 2015, p. 1-27), Hamzah also disclosed a myriad of mystical experiences he experienced individually within the symbols in his poems.

Deriving from the background of the old tradition of Arab's poetry writing, Ibn 'Arabi complied the traditionally poetry writing and its images in reflecting his thoughts with a twist in the meaning while Hamzah brought a new dimension in Malay literature by adapting the suffix symbols of Arabs and Persians in Malay poetry by Malay references to be easily accepted and understood by the Malay community (Abdul Hadi, 2012). He represents the expressions of Sufism interpretations expressed by the Malay's sense of taste but can expose the spiritual feelings experienced by God's lovers. At the same time, the simplicity and expressiveness of the image used by Hamzah still distinguish itself from God even though it is not separated. In this, Hamzah Fansuri has put a standard in Malay's Sufi poetry far beyond his time proving his capacity in becoming Sufi's Malay Sage (Nuraini, 2016, p. 197-206).

Ibn 'Arabi and Hamzah Fansuri also proved that Sufi's poets have highlighted the meaning of divine symbols, and often assimilate them with the verses of the Holy Qur'an and the Sunnah of the Prophet to stress out the thoughts (Ibid) and which show how impossible it is to set the pure language for the human mind (Jaberi, Imran Ho \& Vengadasamy, 2016, p. 143-156).

The similarities inherent in the reforms brought about by these two figures show the existence of the influence-effect elements in which emitters and receivers exist but their uniqueness is still present through the cultural differences of the nation. It is also proven to us that language influences the thought of its speaker and these thoughts collectively mould ones' culture (Zaitul Azma \& Ahmad Fuad, 2011, p. 31-51). 
These signs have the meaning of their own. To comprehend the meaning one must know the poet's background thoroughly as meanings can be conveyed and comprehended denotatively or connotatively as poetry represent the abstractness and imaginations of the poet.

\section{List of References}

al-Quran al-Karim

Abdul Fatah Haron Ibrahim. (2006). "Syari'at, Tareqat, Haqiqat dan Ma'rifat: Suatu Analisa Kritis." Jurnal Penyelidikan Islam, 19, pp. 1-30. Retrieved from http://www.myjurnal.my/public/issueview.php?id=4652\&journal_id=394 [1 October 2020].

Abdul Hadi W. M. (2012). “Jejak Sang Sufi: Hamzah Fansuri dan Syair-syair Tasawufny,” Siri Kuliah Umum "Islam dan Mistisisme Nusantara", Teater Salihara, 21 Julai 2012, Retrieved from https://archive.org/stream/KumpulanARTIKEL-BULETINVol1f/2012-07-21-islam_mistisismehamzah_fansuri_djvu.txt [27 Februari 2018].

Abdul Sattar Awwad Ibrahim (2008). Ambiguity in Poetry: Definition, Function, and Elements. Journal Alustath, Issue 72, 801-816. Retrieved from https://www.iasj.net/iasj?func=fulltext\&aId=43358 [18 January 2018].

Arba'iyah Mohd Noor (2020). "The Transition of Malay Women's Role and Contribution in the Early 20th Century.," Journal of Al_Tamaddun, 15 (1), 67-84. Retrieved from https://doi.org/ 10.22452/JAT.vol15no1.5 [3rd October 2020].

Arina Johari \& Indirawati Zahid (2016). "Manifestasi Kesantunan Melayu dalam Ujaran Memberi dan Meminta Nasihat." GEMA Online ${ }^{\circledR}$ Journal of Language Studies, 16(2), 73-94. Retrieved from http://ejournal.ukm.my/gema/article/view/10982. [13 Januari 2018].

Armstong, Amatullah (1995). Sufi Terminology: The Mystical Language of Islam. Kuala Lumpur: A.S Noordeen.

al-Attas, Syed Muhammad Naguib (1970). The Mysticism of Hamzah Fansuri, Kuala Lumpur: University of Malaya Press.

Babakhani, B., Ardalan, E., \& Seraj, S. (2017). "Comparing the Position of Faith in the Ideas of Kierkegaard and Ibn Arabi with Emphasis on the Meccan Revelations." Journal of History Culture and Art Research, 6 (2), 636-646.

Braginsky, V. Y. (1975). "Some Remarks on the Structure of the "Syair Perahu" by Hamzah Fansuri." Bijdragen tot de Taal-, Land-en Volkenkunde, (4de Afl), 407-426.

Burnahazmi, Yusuf Hadi (1389H). "al-Mar'ah wa al-Khamrah Ramzāni fī al-Syi'ri al-Șūfî," al-Turath alAdabi. 6 (2), 179-191.

Carr, N. (2017). "Symbol and Allegory in Romantic History." New Literary History, 48 (1), 171-192.

Cook, Julian \& Hirstenstein, Stephen. 2012. The Great Diwan and Its Offspring - The Collection and Dispersion of Ibn Arabi's Poetry. Journal of the Mubyiddin Ibn Arabi Society. 52, 33-91. (https://ibnarabisociety.org/wp-content/uploads/PDFs/jmias-52-cook.pdf)

Drewes, G.W.J \& Brakel, L.F. (1986). Bibliotheca Indonesia: The Poems of Hamzah Fansuri. Leiden: Royal Institute of Linguistics and Anthropology.

Dewan Bahasa dan Pustaka (2004). Ensiklopedia Islam. Kuala Lumpur.

Dewan Bahasa dan Pustaka (2005). Kamus Dewan, $4^{\text {th }}$ Ed., Kuala Lumpur.

al-Fairuzabādī, Majd al-Din Muḥammad Yac $q u ̄ b$ (1996). al-Qāmūs al-Muhiț, 5th Ed., Beirut: Mu'assasat alRisalah.

Page | 36 
Ferber, Michael (1999). A Dictionary of Literary Symbols, United Kingdom: Cambridge University Press.

Gril, Denis. 2013. Ibn al-'Arabi in Egypt - The Speech of Things. Journal of the Mubyiddin Ibn Arabi Society, 53. Retrieved from https://ibnarabisociety.org/the-speech-of-things-denis-gril/ [30 September 2020].

Hasymy, A. (1976). Ruba'i Hamæah Fansuri Karya Sastra Sufi Abad XVII. Kuala Lumpur: Dewan Bahasa dan Pustaka.

Ibn Arabi, Mahyuddin bin Ali (n.d). Diwan Ibn Arabi. Nawaf al-Jarrah (ed.), Beirut: Dar Sadir.

Ibn Arabi, Mahyuddin bin Ali (2005). Diwān Tarjumān al-Ashwāq. Abdul Rahman al-Mustawi (ed.), Beirut: Dar al-Ma'rifah.

Ibn Hajar al-cAsqalānī (n.d). Fatḥu al-Bārì Syarḥ Șabīh al-Bukhärì. Muhammad Fuad Abdul Baqi (ed.), 1'st Volume, Riyadh: Dar al-Salam.

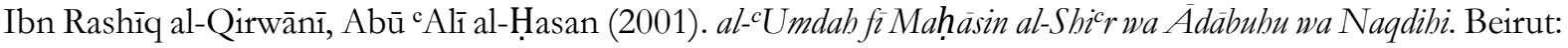
Maktabat al-'Asriyyah.

Jaberi, S., Imran Ho Abdullah \& Vengadasamy, R. (2016). "Mystical Love Metaphors: A Cognitive Analysis of Sohrab Sepehri's Poetry." GEMA Online ${ }^{\circledR}$ Journal of Language Studies, 16(1), 143-156. Retrieved from http://ejournal.ukm.my/gema/issue/view/750. [12 December 2017].

Jajang A. Rohmana (2015). "Sastra Sufistik Melayu dan Sunda di Nusantara: Mempertemukan Hamzah Fansuri dan Haji Hasan Mustapa.” Ibda’ Jurnal Kebudayaan Islam, 13(1), 1-27.

Johansen, Jorgen Dines (2002). Literary Discourse - A Semiotic-Pragmatic Approach to Literature. Canada: University of Toronto Press.

Kamal, M. (2017). "Ibn 'Arabi and Spinoza on God and the World." Open Journal of Pbilosophy, 7, 409-421.

al-Khatib, Ali (1404H). Ittijahat al-Adab al-Süfí bayna al-Halläj wa Ibn 'A Arabi. Kaherah: Dar el-Maarif.

Knysh, Alexander D. (1999). Ibn Arabi in the Later Islamic Tradition: The Making of a Polemical Image in Medieval Islam. Albany: State University of New York Press.

Louwerse, M. \& Qu, Z. (2017). "Estimating Valence from the Sound of a Word: Computational, Experimental, and Cross-linguistic Evidence.”. Psychonomic Bulletin \& Review, 24(3), 849-855.

Lutfi, Huda (1985). "The Feminine Element in Ibn Arabi’s Mystical Philosophy." Alif: Journal of Comparative Poetics, 5,. 7-19.

Mahdavi, B. (2017). "The Role of Allegory and Symbol in Expressing the Fixed Entities in Araghi and Ibne-Arabi's View." Joumal of History Culture and Art Research, 6(1), 817-824.

Mohd Sani Badron (2013). Ibn al-Arabi's Conception of Religion. 2nd Ed. Kuala Lumpur: Penerbit IKIM.

Muhammad Luthfi. 2020. Divine Love in Ibn Arabi, Hamzah Fansuri, and Emha Ainun Nadjib's Poems. Journal of Xi'an University of Architecture \& Technology. XII (III), 3620-3631. (http://www.xajzkjdx.cn/gallery/311-mar2020.pdf)

Nasr, Atif Jawdah (1983). al-Ramzal-Sbi'r inda al-Sufiyyah. 3rd Ed., Beirut: Dar al-Andalus.

Nuraini H. A. Mannan (2016). "Karya Sastra Ulama Sufi Aceh Hamzah Fansuri Bingkai Sejarah Dunia Pendidikan.” Substantia, 18 (2), 197-206. Retrieved from https://core.ac.uk/download/pdf/228453764.pdf [30 September 2020].

Orfali, B. (2017). "Mystical Poetics: Courtly Themes in Early Sufi Akhbār." Pomerantz, M.A. \& Vitz, E. B. (ed), in In the Presence of Power: Court and Performance in the Pre-Modern Middle East. New York: New York University Press, 196-214. 
al-Qushayri, Abu al-Qasim Abd al-Karim Huwazan (n.d). al-Risalah al-Qushayriyyah. Kaherah: Matba'ah Hassan.

Rahman Shaari (2001). Bimbingan Istilah Sastera. Kuala Lumpur: Utusan Publications.

Sebeok, Thomas A. (2001). Signs: An Introduction to Semiotics. $2^{\text {nd }}$ Ed. Canada: University of Toronto Press Incorporated.

Sa'diyya Shaikh (2012). Sufi Narratives of Intimacy: Ibn Arabi, Gender, and Sexuality. United States of America: The University of North Carolina Press.

Sajad Hussain Wani (2016). "Sufi Poetry and Symbolism: From a River to the Divine Dark in Shamas Faqir's Poetry." Language in India, (16), 200-221.

Samiha Nesraoui (2016). "al-Ramz al-Sufi: Dirasah Ta'wiliyyah.” Nadi al-Adab: Jumal Ilmiah Bahasa, Sastra, Seni dan Kebudayaan Arab. 13(2), pp. 8-20.

Sharvani, Z. A. K., \& Sattar, S. A. (2017). "Visishtādvaita and Wahdatul-Wujūd: Points of comparison and departure." Tattva-Journal of Philosophy, 8(1), 1-18.

Susanti, E. (2014). “Budaya Malu Cerminan bagi Perempuan Melayu.” Sosial Budaya, 11(2), 226-236.

Syarifuddin (2017). Memperdebat Wujudiyah Sheikh Hamzah Fansuri - Kajian Hermeneutik atas Karya $\begin{array}{lllll}\text { Sastra Hamzah } & \text { Fansuri. Religia, } & 13 & \text { (2), }\end{array}$ (https://www.researchgate.net/deref/http\%3A\%2F\%2Fdx.doi.org\%2F10.28918\%2Freligia.v13i2. 179).

al-Thacālabī, Abū Manșūr Ismā̄î̀ al-Naysābūrī (n.d). Kitāb Fiqh al-Lughah wa Sir al-c Arabiyyah. Beirut: Dar al-Kutub a-'Tlmiyyah.

Wan Mohd Saghir Abdullah (1996). Tafsir Puisi Hamzah Fansuri dan Karya-karya Sufi. Kuala Lumpur: Khazanah Fathaniyah.

Widdowson, H.G. (2000). Practical Stylistics: An Approach to Poetry. $2^{\text {nd }}$ Ed., Oxford: Oxford University Press.

Zakaria Stapa (1993). Ibnu Arabi Tokoh Sufi. Kuala Lumpur: Dewan Bahasa dan Pustaka.

Zaitul Azma Zainon Hamzah \& Ahmad Fuad Mat Hassan (2011). "Bahasa dan Pemikiran dalam Peribahasa Melayu." GEMA Online Journal of Language Studies, 11(3), 31-51. Retrieved from http://ejournal.ukm.my/gema/issue/view/27. [12 Disember 2017].

Zargar, C. A. (2016). "Allegory and Ambiguity in the Films of Majid Majidi: A Theodicy of Meaning." Journal of Religion \& Film, 20(1), 1-32.

Zurakintan Abdul Razak \& Che Ibrahim Salleh (2015). "Pemikiran Melayu tentang Ilmu dan Adab dalam Puisi Melayu Ttradisional." International Journal of the Malay World and Civilisation, 3(2), 121-129. 